DOI: 10.1515/pof-2016-0001

VOLUME 8, ISSUE 1, 2016

ISSN: $2036-5438$

\title{
Another Brick in the Whole. The Case-Law of the Court of Justice on Free Movement and Its Possible Impact on European Criminal Law
}

by

Leandro Mancano*

Perspectives on Federalism, Vol. 8, issue 1, 2016 


\begin{abstract}
European Union, and criminal, laws had been interacting in many ways even before explicit competence in criminal matters was acquired by the Union in the Treaty of Maastricht. Such intersections between supranational and national provisions have frequently been handled by the CJEU. In the main, the intervention of the Court is triggered by Member States' recourse to penal sanctions in situations covered by EU law. In such cases, the CJEU is called upon to strike a complicated balance: it has to deal with Member States' claims of competence in criminal law, whilst ensuring that that power is used consistently with EU law. By making reference to selected cases, this paper highlights the impact that principles established in the context of the fundamental freedoms can have on EU criminal law.
\end{abstract}

Key-words

Free movement, EU criminal law, mutual recognition, proportionality, fundamental rights, Court of Justice of the European Union 


\section{Introduction}

European Union $(\mathrm{EU})^{\mathrm{I}}$ law is not just a framework of coexisting watertight areas. Quite the opposite, it is a 'whole' whose constituent parts are highly connected and influence each other. As time has gone by, many bricks have built up and strengthened such a connection, with the Court of Justice of the European Union ('the Court' or the 'CJEU') playing a major role in this respect. This paper aims to put another brick in this 'whole', and to discuss how the Court's case-law on free movement can improve fundamental rights' protection in EU criminal law. By EU criminal law, I mean: the instruments adopted by the Union according to the competences conferred in the Treaty, ${ }^{\mathrm{II}}$ as well as the law of the former 'third pillar'; the interaction between EU and national criminal law.

Interdependence is an inherent feature in the EU; where interaction takes place not only among the different areas of Union law, but also between the latter and national systems. This is even truer as far as penal law is concerned. Many principles usually traced back to EU criminal law have been firstly stated and developed in the context of free movement. What is more, in many cases this has resulted in heightening the standard of protection of individual rights. Three different expressions of interaction can be seen

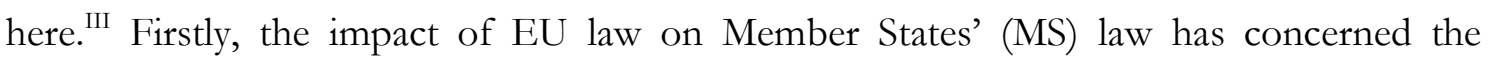
infringements of EU law provisions, criminalised at national level, where the CJEU has set aside those MS' rules that limited the rights established by EU law in a disproportionate manner. ${ }^{\text {IV }}$

Secondly, the use of criminal penalties has been upheld by the EU as a tool in maintaining the effectiveness of EU law. The "Greek Maize" case is the landmark judgment in this respect. ${ }^{\mathrm{V}}$ The Court, by founding its reasoning on effectiveness, established the principle of assimilation. Here the obligation is for MS to treat comparable violations of Community and national law with analogous means, for MS reactions to amount to effective, proportionate and dissuasive penalties, and for these to be enforced with the same diligence as those applied to national situations. Though initially used in isolation, the Greek Maize 'formula' has progressively been accompanied by an explicit obligation for MS to impose penalties involving deprivation of liberty. 
In the third way of interaction, criminal law principles have been regarded as general principles of EU law, particularly in order to ensure the application of Union law in compliance with the principles of legal certainty and non-retroactivity in criminal proceedings. ${ }^{\text {VI }}$ The Treaty of Lisbon has resulted in the enhancement of the potential in terms of mutual impact among the different areas of EU law; which can be mostly ascribed to the collapse of the pillar-based structure of the EU.

In this respect, the existing case-law of the Court offers further opportunities to strengthen the protection of individuals in EU criminal law through the use of the principles stated in the context of free movement. Broadly speaking, the interplay between criminal law and free movement has increased at the EU level over the years, with two broad fronts of interaction emerging in particular. On the one hand, we have seen the use of the legal rules, and their interpretation by the CJEU, where criminal law is overtly resorted to. In the Area of Freedom Security and Justice (AFSJ), criminal law is explicitly used in EU instruments since the Union has specific competences in this respect. On the other hand, there are extensive areas of EU law where criminal law is not mentioned, since this would fall outside the Union powers; this is the case of the internal market and fundamental freedoms. In this way penal rules are put under the spotlight by the interaction between EU and national laws, with the Court deliberating on the role attached to criminal penalties.

The high relevance of the interaction between fundamental freedoms (or, more broadly, Union law) and criminal law has been extensively analysed. ${ }^{\text {VII }}$ Indeed, free movement has been, and is, the core of EU law since the latter was born, though many other areas have been gaining ground over the years (such as citizenship and criminal law). Right from the establishment of the EU, national provisions of criminal law have been increasingly covered by the law of the four freedoms (consisting of the Treaty and secondary law). Thereby, the chance for both kinds of rules (national and supranational) to interact has significantly heightened. Such dynamics have triggered many interpretative dilemmas, the resolution of which have been referred to the CJEU by national judges. In these contexts, the CJEU has been asked to find an equilibrium between economic freedoms and state sovereignty in criminal law. Two fundamental questions arise in this respect: is criminal law restricting, or capable of restricting, a fundamental freedom; and if so, may such a restriction be allowed? 
Many studies have focused on the use of general principles by the CJEU in this area, and its impact on criminal law. Therefore, in this paper I discuss possible consequences for EU criminal law that have not been explored in-depth so far. I select a restricted number of Court's rulings, and outline two main scenarios. As for the choice of the judgments, a key criterion has been the value of primary law taken on by the Charter of Fundamental Rights of the EU (CFREU or the Charter). I am interested in dealing with the possible impact of free movement case-law on fundamental rights in EU criminal law. Therefore, I analyse those judgments explicitly referring to a fundamental right or a general principle now enshrined in the Charter.

The first scenario regards the use of the principle of proportionality; here I argue that the CJEU's use of the principle where criminal law encounters the fundamental freedoms has been largely beneficial to individuals. Such interactions have given the Court the opportunity to develop a manifold application of the principle of proportionality to criminal penalties featured at the national level. In this part I present the cases of Skanavi ${ }^{\text {IX }}$ and Awoyemi. ${ }^{\mathrm{x}}$ As mentioned above, there is an extensive case-law of the Court's limitation of MS's use of criminal penalties in light of the principle of proportionality. Such a restraint has often been based on the argument that the measure in question was so disproportionate that it hampered the exercise of free movement. I decided to focus on Skanavi and Awoyemi as they examined exactly the same situation (driving in a host Member State with a non-recognised licence) and the same penalty (criminal sanctions, in particular imprisonment and a fine). The only difference lies in that Mrs Skanavi was an EU national, while Mr Awoyemi was not. Therefore, I jointly read these two decisions to contrast the differences between the proportionality test applied by the Court to an EU citizen, and that applied to a third-country national.

From this, I stress the importance of EU citizenship to the application of proportionality in criminal law. Admittedly, these judgments were issued before the adoption of the Charter; however, the CFREU now provides for the universal principle of proportionality of penalties in Article 49(3). I argue that the relationship established by the Court between the enjoyment of such a principle and the entitlement to free movement requires clarification, in light of the legally-binding value taken on by the Charter.

The second scenario concerns the possible non-implementation of EU secondary law on fundamental rights grounds, where I deal with the Berlusconi ${ }^{\mathrm{XI}}$ and Caronna ${ }^{\mathrm{XII}}$ rulings. In 
this scenario, the cases form part of a consistent case-law of the Court of Justice, according to which criminal liability cannot be directly determined or aggravated by EU law, without a national law of implementation. Here I argue that the Court allowed the possible noncompliance of national law with EU secondary law. It did so by arguing that the implementation of the latter might have caused the infringement of a general principle or a fundamental right. At stake in particular was the principle of legality now enshrined in Article 49 CFREU. The first reason for choosing these cases is that the CJEU backed up its argument by explicitly referring to a general principle (as is the case of Berlusconi) or a fundamental right of criminal law (Article 49 Charter in Caronna).

Furthermore, in Berlusconi the Court was faced with the contrasting effect of three subsequent laws: (1) EU company law; (2) the first Italian law which correctly implemented it, by the introduction of effective (criminal) penalties for violations of EU law; (3) the subsequent Italian law, which partially decriminalised offences provided for in the first law, and posed for that reason serious doubts of compatibility with the Union rules concerned.

The preliminary ruling arose in the context of criminal proceedings, which regarded conducts (allegedly) committed under the first Italian law, but which were then decriminalised by the second one. However, the latter law was potentially not in compliance with EU law for lack of effectiveness. The Court was essentially asked as to whether such non-compliance could result in setting aside the subsequent Italian law, so opening the door to the criminal liability of the persons concerned.

The scenario depicted makes Berlusconi a perfect showcase for analysing the relationship between the implementation of EU secondary law and the protection of fundamental rights. Likewise, Caronna concerned the possibility of determining criminal liability directly on the basis of an EU directive. In that judgment the Court was clear in finding that respect for the Charter would prevail even where national law is contrary to EU law. As clarified below, I argue that the rationale behind the decisions in the second scenario provides EU criminal law with an important tool to better protect fundamental rights in the context of mutual recognition.

The article is structured as follows. I firstly deal with the scenario regarding proportionality, and I present the cases of Skanavi and Awoyemi. I then discuss their importance for EU criminal law, taking into consideration in particular Article 49(3) CFREU. Secondly, I address Berlusconi and Caronna. In this part I try to show how the cases 
can be highly relevant to mutual recognition in criminal matters. Lastly, I recall the topics touched upon, and I argue that the case-law of the CJEU can be used to enhance protection of individuals.

\section{EU Citizenship and Proportionality}

\subsection{Skanavi and Awoyemi}

The question in Skanavi arose in the context of criminal proceedings against Mrs Skanavi and her husband, Mr Chryssanthakopoulos, who were charged with driving without a licence. According to German Law, the conduct was an offence punishable by imprisonment or a fine. As far as EU law is concerned, driving licences were first harmonised by First Council Directive 80/1263/EEC of 4 December 1980 on the introduction of a Community driving licence. ${ }^{\mathrm{XIII}}$ That instrument in particular set a system for the mutual recognition and the exchange of driving licences, when the holder had her/his residence or workplace in another MS. By virtue of that directive, when the holder of a valid driving licence took up residence in another MS, the licence would remain valid for up to a maximum of a year after the establishment of residency. At the request of the holder within that period, and against surrender of the licence, the host MS was to issue the driver with a Community model driving licence for the corresponding category or categories without requiring the holder, inter alia, to pass a practical and theoretical test or to meet medical standards. According to the subsequent Directive 91/439/EEC, ${ }^{\text {XIV }}$ the holder of a valid driving licence residing in another MS was not obliged to exchange it.

The Court was firstly asked whether, as EU law stood prior to the implementation of the latter directive, a MS could require the holder of a driving licence issued by another MS to exchange that licence within one year from the establishment of the residence in the host State, in order to retain the entitlement to drive in the state. The Court recognised that the rules concerning driving licence can have a significant impact on the freedom of movement for workers, as well as on the freedom of establishment and provision of services. ${ }^{\mathrm{XV}}$ The Court also found that the gradual harmonisation carried out at EU law level allowed MS to retain some powers in this respect. Such a latitude included requiring the holder of a valid licence to exchange it in the MS where s/he had moved to. 
The Court was further asked whether the Treaty precluded the act of driving of a motor vehicle by a person who had not exchanged licences from being treated as driving without a licence, and thus rendered punishable by imprisonment or a fine. The Court acknowledged that the obligation to exchange the licence was compatible with EU law, but also that it constituted a mere administrative requirement.

Though the MS remain competent with regard to the use of criminal law, the latter must be used in such a way as not to obstruct free movement. This is especially the case when it comes to imprisonment, ${ }^{\mathrm{XVI}}$ where on that ground the CJEU ruled that EU law prohibited MS from treating driving without the exchanging of the licence as a criminal offence, since it would jeopardise the enjoyment of free movement. ${ }^{\mathrm{XVII}}$

Awoyemi regarded exactly the same situation as that occurred in Skanavi, but the difference laid in the fact that the person concerned was a third-country national. The Court was asked whether EU law precluded MS from treating driving without exchanging a licence as a criminal offence. The Court found that the former directive applied irrespective of nationality, and also recalled Skanavi, when stating that MS must use criminal law in compliance with EU law and the principle of free movement. ${ }^{\mathrm{XVIII}}$ However, the Court found that a person such as Mr Awoyemi, as a third-country national, may not rely on the principle of free movement of persons, which applies only to a national of a MS. ${ }^{\mathrm{XIX}}$ As the law stood at that moment, the position of the person concerned was not governed by provisions of EU law, as he was not entitled to free movement.

The Court mitigated this statement by means of the principle of retroactivity of a more favourable norm. The Court relied on the applicability of Directive 91/439/EEC on driving licences, which in the interim had substituted Directive 80/1263/EEC. The newest directive imposed on MS the prohibition of the requirement to exchange driving licences issued by another MS, regardless of the nationality of the holder. The Court recognised that the situation of $\mathrm{Mr}$ Awoyemi fell under the principle that an individual may rely against the State - on provisions of a directive which are unconditional and sufficiently precise, where that State failed to: transpose the directive within the prescribed period, or implement the directive correctly. ${ }^{\mathrm{xx}}$ On that ground, the Court found that EU law allowed a national judge, by reason of the principle that forms part of national law in certain MS of the retroactive effect of more favourable provisions of criminal law, to apply such a provision even where the offence took place before the date set for compliance with that 
directive. The Court recalled the principle of the retroactive effect of more favourable provisions of criminal law.

\subsection{Impact in Terms of Proportionality}

The cases discussed above are highly relevant to EU criminal law, and they are also interesting because judgements were given when the Charter did not have legally-binding value. Therefore, it is appropriate to raise the question as to how the principle stated therein can be upheld in the EU legal framework as developed by the Treaty of Lisbon. At stake there is in particular the interaction between different understandings of the principle of proportionality. As is well-known, that principle has been used to balance (inter alia) fundamental freedoms and national laws. Eminent scholars have debated on the principle of proportionality in general terms, ${ }^{\mathrm{XXI}}$ as well as with particular reference to EU law. ${ }^{\mathrm{XII}}$ In the latter area, it has been highlighted that the multiform application of proportionality depends on the peculiarities of the area of law at stake, and the nature of the interests involved. ${ }^{\text {XXIII }}$

As provided for in Article 5 of the Treaty of EU (TEU), proportionality is a polestar (jointly with the principle of subsidiarity) for the Union in the application of its competences. The proportionality test famously provides that: the means adopted are appropriate to achieve the objectives legitimately pursued (suitability test); the means adopted are necessary in order to achieve the objectives legitimately pursued (necessity test); and the means adopted should not impose an excessive burden on the individual (proportionality stricto sensu). Put simply, the principle of proportionality under EU law requires that a legitimate aim be pursued through the least intrusive measure for individuals. Furthermore, Article 52 CFREU states that limitations on the exercise of the rights and freedoms recognised by the Charter are subject to the principle of proportionality. In this sense, evaluating criminal law on the basis of this principle of proportionality is to examine how the MS justify their use of criminal law, and more specifically, how criminal law is related to a given objective, and which function the former is supposed to fulfil.

However, this principle has also a criminal law understanding. ${ }^{\text {XxIV }}$ Scholars have written extensively on the reach of proportionality ${ }^{\mathrm{xxv}}$ at EU criminal law level, and on its interaction with the principle of subsidiarity in criminal law. ${ }^{\mathrm{x} v \mathrm{I}}$ Given that the debate on 
the meaning of these principles is huge, I can just try to simplify it for the purposes of this paper. The interaction between the meanings of proportionality and subsidiarity in EU law and $(\mathrm{EU})$ criminal law is highly relevant. As they can overlap and be understood in more than one way, their interaction can significantly impact on the individuals concerned.

Subsidiarity in criminal law (also known as ultima ratio or last resort principle) means that penal sanctions should be resorted to only where other instruments would be insufficient to protect the interests at stake. This is the outer dimension of ultima ratio, ${ }^{\mathrm{XXVII}}$ which looks at criminal law in relation to other less intrusive legislative means. As Husak states, it focuses on the alternatives to punishment, rather than on what kind of punishment to prefer and alternative means of punishment. ${ }^{\text {XxvIII }}$

In this sense, Giudicelli-Delage argued that the necessity under EU law proportionality test is imbued not only with a utilitarian logic (relation between means and end), but also with the principle of criminal law as ultima ratio. Therefore, such a necessity would cover two fundamental guarantees: punishing "as long as it is useful and as long as it is fair. The legitimacy of punishment rests on its fairness and usefulness. The combination of these two principles is key to establishing conditions and limits of punishment (...), since considering both of them in isolation would lead to dangerous consequences". xxIx

Such a picture is made even more complicated by the advent of the Charter with a legally-binding value, where Art. 49, ${ }^{\mathrm{xx}}$ established the proportionality test between the level of punishment and the seriousness of the offence. Furthermore, the evaluation of proportionality under criminal law involves both the legislative and the sentencing levels, that is to say the penalties as provided by the law and applied to the concrete cases by the judges. ${ }^{\text {xxxI }}$

The Court's judgments in Skanavi and Awoyemi show exactly the importance of these different understandings. In the cases, the application of the principle of proportionality has been linked to the entitlement to free movement, which applies to persons satisfying the following conditions: being an EU citizen; having moved to another MS; having been, or being engaged in some economic activity in the MS where s/he has moved to. The reach of the Treaty freedoms is expanded to include covering the driving licence system. As such the protection offered by free movement law is significantly enhanced, so that the compatibility of criminal sanctions with EU law is tested in light of this enlarged dimension. The consequence is evident: the broader the area within which criminal law is 
required to be consistent, the higher the chances that it will be found not in compliance with EU law. Personal liberty might have been treated as an instrument for the purposes of exercising an economic freedom. More than one question arises in this respect: are there penalties which are disproportionate while not hindering free movement, and if so, how could they be justified? However, one should not overlook that in cases such as those discussed, the Court ruled on the compliance of a national measure with Treaty freedoms, so that the latter are assumed as a benchmark of lawfulness. Furthermore, in a way the CJEU is deciding on the fairness of a national criminal law system, in a moment where a (weak) Union competence in criminal matters had just come into being.

Nonetheless, such an approach may have its drawbacks, as seen in Awoyemi; in this case the Court was true to the general principle according to which the free movement law applies only to EU citizens, so that an individual may be subject to a penalty which the Court has explicitly recognised as disproportionate, if applied to EU citizens. One may uphold the CJEU coherence as follows; a criminal penalty is disproportionate where related to the exercise of free movement, that sanction ceases to be disproportionate, when applied to a person not entitled to free movement.

Granted, there are at least two elements that must be considered in the analysis of the case. Firstly, at that time the Charter had not yet been adopted. Secondly, the Court might have opted for that interpretation because there were no elements capable of triggering the application of EU law. Indeed, at stake there was the protection of the exercise of free movement. The principle of free movement could not apply, because in that case $\mathrm{Mr}$ Awoyemi fell outside the scope of EU law: neither the Treaty, nor secondary law, governed that situation.

That said, it must be pointed out that there was relevant EU law in the area, namely Directive $91 / 439 /$ EEC, confirmed by the fact that the Court resorted to it when applying the principle of retroactivity of more favourable provisions of criminal law. However, it was not considered a matter of EU law because the person concerned did not enjoy free movement.

The main problem in upholding such a hands-off approach is that it takes for granted the link between the application of the principle of proportionality and the entitlement to free movement. Indeed, the Court found that the penalty was lawful, and proportionality did not apply exactly, because that principle was subject to the exercise of free movement. 
This caveat notwithstanding, I submit that Awoyemi should be regarded as a case on the proportionality of penalties, rather than a case on the application of free movement.

The advent of legally-binding value with the CFREU seems to corroborate such an interpretation. If the Court were to be asked the same question today, the following circumstances would be taken into account. Firstly, Article 51 CFREU states that the Charter applies when MS implement EU law. In a case such as Awoyemi, it would be difficult affirming the non-application of the CFREU, since the national law would be implementing EU law. ${ }^{\text {XxII }}$

Secondly, Article 49(3) lays down the universal principle that the entity of penalties must be proportionate to the seriousness of the offences. Arguing for the application of such a principle to EU citizens only would seem rather unsound. In light of these arguments, there appears to be the possibility that the Charter challenges the wellestablished link between the entitlement to free movement and the principle of proportionality of penalties. ${ }^{\text {xxiII }}$ Otherwise, the right to free movement would become a prerequisite of the enjoyment of fundamental rights, which appears in sharp contrast to the framework provided for in the Treaties. Now I move on to the second scenario, where I discuss Berlusconi and Caronna, and their possible importance for judicial cooperation in criminal matters within the EU.

\section{Hierarchy and Compliance with EU Law and Refusal of Mutual Recognition}

\subsection{Berlusconi and Caronna}

The Berlusconi case concerned the interaction between EU company law and the implementing Italian law, where, in compliance with EU company law, Italian law initially provided for effective (criminal) penalties. However, the law was subsequently amended by a subsequent law, which decriminalised the specified conducts to some extent. The referral for a preliminary ruling arose in the context of criminal proceedings that concerned facts dating back the first version of the Italian law. As a consequence, the alleged behaviour could have been subject (in theory) to criminal liability. On the other hand, the subsequent legal framework introduced by the newer law set a regime more favourable to the accused, but potentially less effective than the former one. Therefore, at stake here was a contrast 
between the need for effective penalties at national law level for infringements of EU law (embodied by the first Italian law), and the respect of the principle of retroactivity of more lenient penalties in criminal law.

The Court firstly stated that the principle of the retroactive application of the more lenient penalty is a general principle of EU law, which 'national courts must respect when applying the national legislation adopted for the purpose of implementing EU law' (emphasis added). ${ }^{\mathrm{x} x \mathrm{IV}}$ Following the latter principle would have led to the application of the subsequent Italian law, potentially contrary to EU law.

The Court further found that, in case of non-compliance of the national law with EU law, 'the national courts would be required to set aside, under their own authority, those new articles without having to request or await the prior repeal of those articles by way of legislation or any other constitutional procedure. ${ }^{\mathrm{xxxv}}$ However, the Court also recalled the principle that a directive cannot determine or aggravate criminal liability, in the absence of a national law of implementation. ${ }^{\mathrm{XxVI}}$ As the application of EU law, and the consequent disapplication of the newer Italian law, could have set aside those two principles (retroactivity and requirement of national law for criminal liability), the Court concluded that the provisions of EU secondary law in question 'cannot be relied on as such against accused persons by the authorities of a MS within the context of criminal proceedings. ${ }^{\text {XxxvII }}$

Caronna regarded the interpretation of Directive 2001/83/EC on medicinal products for human use, ${ }^{\text {XxxvIII }}$ and the Italian law implementing it. The Directive imposed on the MS a general obligation to make the wholesale distribution of medicinal products subject to the possession of a special authorisation. Such an obligation should also apply to 'persons authorised or entitled to supply medicinal products to the public if they may also engage in wholesale business. ${ }^{\text {xxxix }}$ This also concerned pharmacists, who according to Italian law are authorised to operate as wholesalers in medicinal products. The Italian law correctly implemented the Directive through Decree 219/2006. Following amendments introduced over the years, that law also treated wholesale distribution without authorisation as a criminal offence.

The criminal liability of $\mathrm{Mr}$ Caronna was precisely based on the Italian law implementing the Directive. Doubts arose as to whether the law applicable at the material time in the main proceedings made pharmacists subject to the requirement of a special 
authorisation and, in case of infringement, to criminal liability. If not, criminal liability could have been established only by means of an interpretation consistent with EU law, as it was not explicitly stated by a national provision. In this regard, the Court firstly reaffirmed the principle that a directive cannot, of itself and independently of a national law adopted by a MS for its implementation, have the effect of determining or aggravating the liability in criminal law of persons who act in contravention of the provisions of that directive. ${ }^{\mathrm{XL}}$ More interestingly, the Court concluded that 'the principle that criminal penalties must have a proper legal basis, enshrined in Article 49(1) of the Charter of Fundamental Rights of the European Union, would prohibit the imposition of criminal penalties for such a conduct, even if the national rule were contrary to European Union law (emphasis added). ${ }^{\text {XLI }}$

What emerges from these judgments is that the CJEU establishes a hierarchy in different levels of compliance with Union law. The Court states that fundamental rights and general principles prevail over the full implementation of EU secondary law by MS. In both cases the Court confirmed the adage that EU law can never result in aggravating or determining criminal liability without a national legal basis. More broadly, respect for the principle of legality and the Charter outweighs compliance with EU secondary law.

In the next section, I argue that this case-law can be highly relevant for European criminal law, with particular regard to the possibility to refuse mutual recognition on fundamental rights grounds.

\subsection{The Importance of Mutual Recognition in Criminal Matters}

The application of mutual recognition to judicial cooperation in criminal matters within the EU was firstly decided at the European Council of Tampere in 1998, ${ }^{\text {XLII }}$ and, as known, is a principle borrowed from internal market law. ${ }^{\text {XLIII }}$ Introduced by the CJEU with the Cassis de Dijon judgment, ${ }^{\mathrm{XLIV}}$ it required that a product/economic activity, that has been lawfully produced/marketed/exercised in one MS, should be capable of being marketed into another MS without further burdens or conditions. Such a principle finds a limit in the Treaty exceptions (e.g. public policy or public health) and the mandatory requirements/justifications as elaborated by the Court of Justice. ${ }^{\text {XLV }}$ Thereby, mutual recognition is mostly a sort of negative integration, which facilitates the enjoyment of Treaty rights by the free movements of products and persons under a de-regulatory logic. 
The application of this logic to criminal law has caused a heated debate. ${ }^{\mathrm{XLV}}$ Indeed, in criminal matters, each instrument of mutual recognition concerns one or more kinds of judicial decisions (arrest warrant, custodial sentence, and probation measure) and abolishes the requirement of double criminality for a list of 32 offences. According to this requirement, the conduct at the basis of the judicial act at stake must constitute an offence in the jurisdictions of both the requesting and the requested states. Once that requirement has been removed, the balance in cooperation substantially changes. Indeed, when one of these judicial decisions is issued for one of the 32 conducts by MS 'A' (the issuing MS) to MS 'B' (the executing MS), the latter has to recognise and execute the decision without any further formality. For those offences not included in the list, the double criminality principle remains. However, although the executing MS does not treat that conduct as a crime in its own legal order, it may surrender the person concerned all the same, once the issuing MS has required it. The automaticity of mutual recognition in criminal matters is mitigated by mandatory and optional grounds for refusing the execution, as well as by specific rules leaving some discretion to the executing judge.

The first and most prominent example of mutual recognition in criminal matters is the European Arrest Warrant Framework Decision (EAW FD), ${ }^{\text {XLVII }}$ which aimed at replacing the previous system of extradition between MS. The operation of the EAW in practice brought to the fore the thorny issue of the possible refusal of mutual recognition on fundamental rights grounds. ${ }^{\text {XVIII }}$ That is mainly so because the EAW FD (as many other framework decisions on mutual recognition in criminal matters) do not provide an explicit ground for refusal based on fundamental rights reasons. On the other hand, a standard clause is used, according to which the FD should not have the effect of modifying the obligation to respect fundamental rights and fundamental legal principles as enshrined in Article 6 of the TEU. This article states that the CFREU has the same values as the Treaties, and that the European Convention of Human Rights and the constitutional traditions common to MS form part of the general principles of EU law.

What followed from this was the flourishing of a heated debate, ${ }^{\text {XLIx }}$ fuelled by the caselaw of the Court of Justice on the EAW FD. Indeed, the Court in Radu excluded the refusal of mutual recognition even where it can result in a violation of fundamental rights. ${ }^{\mathrm{L}}$ Thereafter, in Lanigan, the CJEU seemed to open a space by arguing that the EAW FD 
must be interpreted in light of the Charter. ${ }^{\mathrm{LI}}$ Whether or not such a statement can also imply refusal on fundamental rights grounds remains to be seen.

I argue that the case-law discussed above (Berlusconi and Caronna) can be helpful to overcome the stalemate. Whilst concerning different situations, the rationale behind these decisions can be described as follows: the need to comply with 'higher' sources (general principles and fundamental rights) prevails over the full implementation of EU secondary law. Such a principle can be perfectly applied also to mutual recognition. Where there are serious reasons to believe that the execution e.g. of an EAW would result in a violation of a general principle, the relevant mutual recognition instrument of EU secondary law should be set aside. This would be consistent with the broader case-law of the Court, and enhance the protection of individual rights across the EU.

\section{Concluding Remarks}

In this paper, I have tried to show how the case-law of the CJEU issued in the context of free movement can be highly relevant to European Criminal Law.

Firstly, in Skanavi and Awoyemi the Court linked the application of the principle of proportionality to entitlement to free movement. Thereby, EU citizenship comes to the fore as a requirement of the proportionality review. The consequence is that a measure can be regarded as lawful (or not) depending on whether the person concerned is a national of a MS, as such entitled to the exercise of the fundamental freedoms. The advent of the principle of proportionality of penalties under Article 49 CFREU will require clarifications in this respect. Indeed, that provision states a universal principle, and cannot be made subject to requirement of nationality. In this context, one can envisage two possible, unprecedented scenarios. If proportionality were to be applied to third-country nationals, the relationship between entitlement to free movement and the application of the principle of proportionality of penalties would be challenged. Were this not to be the case, free movement could be read as a precondition of access to fundamental rights and personal liberty.

The second way in which the case-law on free movement can be linked to European criminal law regards in particular fundamental rights and mutual recognition. In Berlusconi and Caronna, the Court seems to establish a hierarchy of levels of compliance within EU 
law. The full implementation of EU secondary law should be set aside, when the latter can result in a violation of fundamental rights or general principles. Such a principle can prove helpful to the highly debated possibility to refuse mutual recognition on fundamental rights grounds. Where there is a serious risk of fundamental rights infringement, the relevant legislation should give the way to EU primary law. In this light, a refusal of execution seems to be not only admitted, but also required by EU law to some extent. These scenarios discussed shows that EU law must be considered as a 'whole', and that there is great potential to heighten the standard of protection of the individual throughout the Union.

\footnotetext{
* $\mathrm{PhD}$ in Law, visiting researcher at the University of Copenhagen.

I For the purposes of this article, by 'EU law' I mean the legal framework both post and pre Maastricht.

II In particular, Articles 82 and 83 TFEU.

III See Mitsilegas (2009: 60).

IV ECJ, Case C-203/80, Casati, 1981 ECR 2595; ECJ, Case C-274/96, Bickel and Franz, 1998 ECR I-7637; ECJ, Joint cases C-338/04, C-359/04 and C-360/04, Placanica, Palazzese and Sorricchio, 2007 ECR I-1891.

V ECJ, Case C-68/88, Commission v. Greece, 1989 ECR 2965. See also the forerunner Court's decision, Case C50/76, Amsterdam Bulb, 1977 ECR 137.

VI ECJ, Case C-168/95, Arcaro, 1996 ECR I-06065, paras 36-37; ECJ, Case 384/02 Grongaard and Bang, 2005 ECR I-09939, paras 29-30.

VII Mitsilegas, 2009; Klip, 2012.

VIII On general principles, see above all Tridimas (2006).

Ix ECJ, Case C-193/94, Skanavi and Chryssanthakopoulos, 1996 ECR I-929.

x ECJ, Case C-230/97, Awoyemi, 1998 ECR I-06781.

XI ECJ, Joined cases C-387/02, C-391/02 and C-403/02, Berlusconi and Others, 2005 ECR I-03565.

XII ECJ, Case C-7/11, Caronna, 2012.

XIII First Council Directive 80/1263/EEC on the introduction of a Community driving licence, OJ L 375/1, 31.12.80

XIV Council Directive of 29 July 1991 on driving licences, OJ L 237/1, 24.8.1991.

xv ECJ, Case C-16/78, Choquet, 1978 ECR 2293, para 4.

xVI Case C-265/88 Messner, 1989 ECR 4209, para 14.

xVII Skanavi (n VII), Court's judgment, para 39.

XVIII Ibidem, paras 36 and 38.

XIX ECJ, Case C-147/91, Laderer, 1992 ECR I-4097, para 7.

XX Awoyemi (n VIII), Court's judgment, paras 39-45.

xxI See in particular Alexy (2010: 21-32); Barak (2010: 1-16); Beatty (2004); Endicott (2012); Gerards (2009).

xxiI Among many, see De Búrca (1993: 105-150); Craig (2010: 265- 302); Fontanelli and Martinico (2013: 32-

58); Jacobs (1999: 1-22); Reich (2011); Tridimas (2006).

XXIII See Harbo (2010: 180).

xxiv On the subject Ashworth (2010: 104-155); Robinson and Darley (2004: 173-205); von Hirsch (1992: 5598); von Hirsch and Ashworth (2010: 131-163).

xxv See Asp (2007: 207-219) Bernardi (2012: 15-65); Böse (2011: 34-42); Fichera and Herlin-Karnell (2013: 759-788); Gibbs (2011: 121-137); Sotis (2012: 111-122).

xxvi See on this Asp (2011: 44-55); Donini (2003: 141-183); Herlin-Karnell (2009: 351-361); Kaiafa-Gbandi (2011: 6-33); Melander (2013: 45-64).

XxVII Melander (2013: 51).

XXVIII Husak (2004: 214).

XXIX Giudicelli-Delage (2010: 69). According to the original version, the EU law necessity would imply punishing “pas plus qu'il n'est juste, pas plus qu'il n'est utile. Les principes du juste et de l'utile constituant les
} 
deux éléments sur lesquels repose la légitimité de la peine en se combinant pour en tracer les conditions et limites - combinaison indispensable, (...), car, isolés l'un de l'autre, le juste et l'utile conduiraient à des conséquences également dangereuses".

xxx For a commentary on Article 49 Charter, see Mitsilegas (2014: 1351-1372).

xxxi On the importance of proportionality in sentencing, see van Zyl Smit and Ashworth (2004: 541-560).

XXXII For a recent and thorough assessment of the academic debate on the CFREU's scope of application, also in the light of the recent judgments of the CJEU, see Fontanelli (2014a, b).

XXXIII As noted, the Charter 'puts into the limelight two issues that have been discretely managed in the past by the CJEU, but now demand a clear and direct answer: the division of competences between the Union and its Member States, and the status of the individual as a Union citizen'. See Sarmiento (2013:70).

xxxiv Berlusconi (n IX), Court's judgment, paras 67-69.

xxxv ECJ, Case C-106/77, Amministrazione delle Finanze dello Stato v Simmenthal, 1978 ECR 629, paras 21 and 24; ECJ, Joined Cases C-13/91 and C-113/91, Debus, 1992 ECR I-03617, para 32; ECJ, Joined Cases C-10/97 to C-22/97, Ministero delle Finanze v IN.CO.GE.'90 and Others, 1998 ECR I-06307, para 20.

xxxvi ECJ, Case C-80/86, Kolpinghuis Nijmegen, 1987 ECR 03969, para 13.

xxxviI Berlusconi (n IX), Court's judgment, para 78.

XXXVIII Directive 2001/83/EC of the European Parliament and of the Council of 6 November 2001 on the Community code relating to medicinal products for human use, OJ L 311/67, 28.11.2001.

xxxix Ibidem, Article 77, paras 1-2.

XL ECJ, Case C-60/02, X, ECR 2004 I-00651, para 61.

XLI Caronna (n X), Court's judgment, para 55.

XLII Tampere European Council, 15 and 16 October 1999, Presidency Conclusions.

XLIII Janssen, 2013; Snell, 2014.

XLIV ECJ, Case C-120/78, Rewe v Bundesmonopolverwaltung für Branntwein (Cassis de Dijon), 1979 ECR 00649. XLV Rosas, 2010; Barnard, 2013.

XLVI Among countless publications on the topic, see Mitsilegas (2006: 1277-1311); Peers (2004: 5-36); Lavenex (2007: 762-779). For a state-by-state overview of the application of mutual recognition across EU area, see Vernimmen-Van Tiggelen, Surano, Weyembergh (2009). On mutual recognition and extraterritoriality, see Nicolaidis and Shaffer (2005: 267).

XLVII Council Framework Decision 2002/584/JHA of 13 June 2002 on the European arrest warrant and the surrender procedures between Member States, OJ L 190/1, 18.7.2002, as amended by the Council Framework Decision 2009/299/JHA of 26 February 2009 amending Framework Decisions 2002/584/JHA, 2005/214/JHA, 2006/783/JHA, 2008/909/JHA and 2008/947/JHA, thereby enhancing the procedural rights of persons and fostering the application of the principle of mutual recognition to decisions rendered in the absence of the person concerned at the trial, OJ L 81/24, 27.3.2009.

XLVIII Keijzer and van Sliedregt, 2005; Herlin-Karnell, 2013; Marin, 2014.

XLIX Weyembergh, Armada, Brière, 2014.

${ }^{\mathrm{L}}$ ECJ, Case C-396/11, Radu, para 43.

LI ECJ, Case C-237/15 PPU, Minister for Justice and Equality v Francis Lanigan, nyp, para 54.

\section{References}

- Alexy Robert, 2010, 'The Construction of Constitutional Rights', in Law and Ethics of Human Rights, IV(1): 21-32.

- Ashworth Andrew, 2010, Sentencing and Criminal Justice, Cambridge University Press, Cambridge, 104155.

- Asp Petter, 2007, 'Two Notions of Proportionality', in Nuotio Kimmo (Ed.), Festschrift in honour of Raimo Labti, 2007, 207-219.

- Asp Petter, 2011, 'The Importance of the Principles of Subsidiarity and Coherence in the Development of EU Criminal Law', in European Criminal Law Review, I(1): 44-55.

- Barak Aharon, 2010, 'Proportionality and Principled Balancing', in Law and Etbics of Human Rights, IV(1): 1-16. 
- $\quad$ Barnard Catherine, 2013, The Substantive Law of the EU. The Four Freedoms, Oxford University Press, Oxford.

- $\quad$ Beatty David M., 2004, The Ultimate Rule of Law, Oxford University Press, Oxford.

- Bernardi Alessandro, 2012, 'I principi di sussidiarietà e di legalità nel diritto penale europeo', in Rivista Trimestrale di Diritto Penale dell'Economia, XXV(1-2): 15-65.

- Bernardi Alessandro, 2013, 'Ombre e luci nel processo di armonizzazione dei sistemi penali europei', in Allegrezza Silvia, Grasso Giovanni, Illuminati Giulio, Sicurella Rosaria (eds), Le sfide dell'attuazione di una Procura Europea: definizione di regole comuni e il loro impatto sugli ordinamenti interni, Giuffrè, Milano, 181-264.

- Böse Martin, 2011, 'The Principle of Proportionality and the Protection of Legal Interests (Verhältnismäßigkeit und Rechtsgüterschutz)', in European Criminal Law Review, I(1): 34-42.

- Craig Paul, 2010, 'Proportionality, Rationality and Review', in New Zealand Law Review, XXXV(2): 265302.

- De Búrca Grainne, 1993, 'The Principle of Proportionality' and its Application in EC Law, in Yearbook of European Law, XIII(1): 105-150.

- Donini Massimo, 2003, 'Sussidiarietà penale e sussidiarietà comunitaria', in Rivista italiana di diritto $e$ procedura penale, XLVI(1-2): 141-183.

- $\quad$ Endicott Timothy, 2012, 'Proportionality and Incommensurability', in University of Oxford Legal Research Paper Series, no. 40, available at http://ssrn.com/abstract $=2086622$.

- $\quad$ Fichera Massimo and Herlin-Karnell Ester, 2013, 'The Margin of Appreciation Test and Balancing in the Area of Freedom Security and Justice: A Proportionate Answer for a Europe of Rights?', in European Public Law, XIX(4): 759-788.

- Fontanelli Filippo, 2014a, 'The Implementation of European Union Law by Member States Under Article 51(1) of the Charter of Fundamental Rights', in Columbia Journal of European Law, XX(2): 194-247.

- Fontanelli Filippo, 2014b, 'National Measures and the Application of the Charter of Fundamental Rights to National Measures - Does curia.eu Know iura.eu?', in Human Rights Law Review, XIV(2): 231-265.

- Fontanelli Filippo and Martinico Giuseppe, 2013, 'Browsing The XX Files Necessity in the GATT, and why it is not like proportionality in the EU', in SWUPL International Law Review, Xiamen University Press: 32-58.

- Gerards Janneke H., 2009, 'Proportionality Revire in EU Law', in IV R Encyclopedia of Jurisprudence, Legal Theory and Philosophy of Law,

- $\quad$ Gibbs Alun Howard, 2011, 'Reasoned 'Balance' in Europe's Area of Freedom, Security and Justice', in European Law Journal, XVII(1): 121-137.

- Giudicelli-Delage Geneviève, 2010, 'Droit pénal de la dangerosité - Droit pénal de l'ennemi', in Revue de sciences criminelles et de droit pénal comparé, LXXI(1): 69-80.

- Harbo Tor-Inge, 2010, 'The Function of the Proportionality Principle in EU Law', in European Law Journal, XVI(2): 158-185.

- Herlin-Karnell Ester, 2009, 'Subsidiarity in the Area of EU Justice and Home Affairs Law-A Lost Cause?’, in European Law Journal, XV(3): 351-361.

- Herlin-Karnell Ester, 2013, 'From Mutual Trust to the Full Effectiveness of EU Law: 10 Years of the European Arrest Warrant', in European Law Review, XXXVIII(1): 79-91.

- Husak Douglas, 2004, 'The Criminal Law as Last Resort', in Oxford Journal of Legal Studies, XXIV(2): 207-235.

- Jacobs Francis G., 1999, 'Recent Developments in the Principle of Proportionality in European Community Law', in Ellis Evelyn (ed.), The Principle of Proportionality in the Laws of Europe, Hart Publisher, Oxford, 1999, 1-22.

- Janssen Christine, 2013, The Principle of Mutual Recognition in EU Law, Oxford University Press, Oxford.

- Kaiafa-Gbandi Maria, 2011, 'The Importance of Core Principles of Substantive Criminal Law for a European Criminal Policy Respecting Fundamental Rights and the Rule of Law, in European Criminal Law Review, I(1): 6-33.

- $\quad$ Keijzer Nico and van Sliedregt Elies (eds), 2005, The European Arrest Warrant in Practice, T. M. C. Asser Press, The Hague.

- $\quad$ Klip André, 2012, European Criminal Law: An Integrative Approach, Intersentia, Cambridge. 
- Lavenex Sandra, 2007, 'Mutual recognition and the monopoly of force: limits of the single market analogy', in Journal of European Public Policy, XIV(5): 762-779.

- $\quad$ Marin Luisa, 2014, 'Effective and Legitimate? Learning from the Lessons of 10 Years of Practice with the European Arrest Warrant', in New Journal of European Criminal Law, V(3): 327-348.

- Melander Sakari, 2013, 'Ultima Ratio in European Criminal Law', in European Criminal Law Review, III(1): 45-64.

- Mitsilegas Valsamis, 2006, 'The constitutional implications of mutual recognition in criminal matters in the EU', in Common Market Law Review, XLIII(5): 1277-1311.

- $\quad$ Mitsilegas Valsamis, 2009, EU Criminal Law, Hart Publisher, Oxford.

- Mitsilegas Valsamis, 2014, 'Article 49', in Peers Steve, Hervey Tamara, Kenner Jeff, Ward Angela (eds), The EU Charter of Fundamental Rights. A Commentary, Hart Publisher, Oxford, 1351-1372.

- Nicolaidis Kalypso and Shaffer Gregory, 2005, 'Transnational Mutual Recognition Regimes: Governance without Global Government', in Law and Contemporary Problems, LXVIII(3/4): 263-317.

- Peers Steve, 2004, 'Mutual recognition and criminal law in the European Union: has the Council got it wrong?', in Common Market Law Review, XLI(1): 5-36.

- $\quad$ Reich Norbert, 2011, 'How proportionate is the proportionality principle? Some critical remarks on the use and methodology of the proportionality principle in the internal market case law of the CJEU', available at http://www.jus.uio.no/ifp/forskning/prosjekter/markedsstaten/arrangementer/2011/freemovement-oslo/speakers-papers/norbert-reich.pdf.

- Robinson Paul H. and Darley John M., 2004, 'Does Criminal Law Deter? A Behavioural Science Investigation', in Oxford Journal of Legal Studies, XXIV(2): 173-205.

- $\quad$ Rosas Allan, 2010, 'Life after Dassonville and Cassis: Evolution but No Revolution', in Poiares Maduro Miguel and Azoulai Loïc (eds), The Past and Future of EU Law. The Classics of EU Law Revisited on the 50th Anniversary of the Rome Treaty, Hart Publisher, Oxford, 433-446.

- Sarmiento Daniel, 2013, 'Who's Afraid of the Charter? The Court of Justice, National Courts and the New Framework of Fundamental Rights Protection in Europe, in Common Market Law Review, L(5): 12671304.

- Snell Jukka, 2014, 'The Internal Market and the Philosophies of Market Integration', in Barnard Catherine and Peers Steve (eds), European Union Law, Oxford University Press, Oxford, 300-323.

- Sotis Carlo, 2012, 'I principi di necessità e proporzionalità della pena nel diritto dell'Unione europea dopo Lisbona', in Diritto Penale Contemporaneo, II(1): 111-122.

- Tridimas Takis, 2006, The General Principles of EU Law, Oxford University Press, Oxford.

- van Zyl Smit Dirk and Ashworth Andrew, 2004, 'Disproportionate Sentences as Human Rights Violations', in The Modern Law Review, LXVII(4): 541-560.

- Vernimmen-Van Tiggelen Gisèle, Surano Laura, Weyembergh Anne, 2009, The future of mutual recognition in criminal matters in the European Union, Editions de l'Université de Bruxelles, Bruxelles.

- von Hirsch Andrew, 1992, 'Proportionality in the Philosophy of Punishment', in Crime and Justice, XVI(1): 55-98.

- von Hirsch Andrew and Ashworth Andrew, 2010, Proportionate Sentencing: Exploring the Principles, Oxford University Press, Oxford, 131-163. 